\title{
Understanding Barriers to Utilization of Maternal and Childhood Services through Community Dialogue in the Context of Result Based Financing
}

\author{
Article by Priscilla Kusena \\ Public Health, Texila American University, Guyana, South America \\ E-mail: priscillamadzikus@gmail.com
}

\begin{abstract}
Zimbabwe is implementing a Result Based Financing program since 2011, which was designed to improve utilization of maternal and child health services offered by public health facilities. Four years after the program inception, reports of low vitamin A coverage and, high home deliveries are common. The study sought to understand why there is still low uptake of maternal and child health services. Using cases of Mazowe district health facility catchments, community dialogues were employed to explore underlying causalities to low maternal and childhood health services uptake. Qualitative data analysis methods of transcribing, organizing, categorizing, and coding were used to sift themes and emerging issues. Out of 135 community leaders who participated in this study, we found poor accessibility of health facilities (high transport cost, poor road network, long walking distance and unavailability of outreach services), limited health service promotion, and socio-cultural beliefs (clients linked early attendance for antenatal care with abortion from bewitchment) as major barriers to health service utilization in the study community. We also found dialoguing a good method to inform, educate and stimulate collective responsibility towards improving health services uptake in our study communities. We suggest that health programs in Zimbabwe should consider improving accessibility of health facilities, promotion of health services and increase dialoguing with communities on cultural barriers in order to increase the impact of Results Based Health Financing Programs.
\end{abstract}

Keywords: Barriers, Utilization, Maternal and Childhood Services, Community dialogue, Results Based Financing.

\section{Introduction}

Cordaid Zimbabwe is jointly implementing a Result Based Financing (RBF) program for maternal and child health services with the Ministry of Health and Child Care (MoHCC) in Mazowe District. The program is being implemented in 20 primary and 3 secondary level care facilities. The RBF program is cofunded by the Government of Zimbabwe and the World Bank. Results Based Financing program is intended to improve utilization of Maternal and Child Health services (MCH) through offering free service at health facilities.

Even though the program has been running since 2012, Vitamin A coverage to under-fives remained low, that is $18 \%$ for Makope Clinic and $50 \%$ for Holme Eden Clinic. This is below $90 \%$ district target (Mazowe District Result Based Management Work plan, 2015). Percentage home deliveries should be below $10 \%$ but selected health facilities had over $40 \%$ home deliveries. For Antenatal Care Services under 16 weeks' initial bookings, Makope clinic had 29\%, Belgownie Clinic-31\%, Christon Bank Clinic-45\% compared to the expected district target of 90\% (Mazowe District Result Based Management Work plan, 2015). This necessitated a qualitative study to understand the barriers to utilization of MCH services. The purpose of the study was to examine the underlying factors influencing under-utilization of $\mathrm{MCH}$ services, determine the role of community dialogues in discussing barriers to utilization of $\mathrm{MCH}$ services and to develop participatory micro-action plans with community leaders. 
DOI: $10.21522 / \mathrm{TIJPH} .2013 .05 .04 . A r t 034$

ISSN: $2520-3134$

\section{Methods}

The study used qualitative in depth case study research method which employed the use of community dialogues in Mazowe district. Studied health facilities were selected based on their performance against RBF MCH indicators for July-December 2014. Four health facilities were selected which are Belgownie Clinic, Holme Eden clinic, Makope Clinic and Christon bank Clinic.

A total of 135 community leaders were purposely selected. Community dialogues were done following a discussion guide. Voice recording and complimentary written notes were taken. The researcher utilized a summary form for immediately capturing pertinent information from the dialogue soon after finishing the dialogue discussion. The researcher summarized main issues from the dialogue together with the group at the end of each community dialogue. Salient issues were captured for further recommendations.

Data was analyzed using content analysis. Analysis included steps of transcribing, organizing, categorizing, and coding data for theme assessment. Data validation and triangulation with secondary data was done to eliminate potential sources of bias.

\section{Results, analysis and interpretation}

A total of 135 community leaders participated in community dialogues. Eighty were men and 55 were women. Four thematic areas emerged from the research. These are: accessibility, socio-cultural beliefs, lack of information and education, and attitude of health care provider. Participants mentioned that community dialogues are informative, educative and provide opportunity for shared decision making. The identified micro action plans per health facility are implementable using available resources.

\section{Accessibility}

Participants from the study pointed out that unavailability of transport, long distance of travel to health facility, high consumer cost and unavailability of outreach services in the community may influence utilization of $\mathrm{MCH}$ services.

\section{Transport unavailability}

Availability of transport may influence utilization of health services. Participants from the four health facilities confirmed that there was inadequate transport to move from one place to another. Moreover, Holme Eden, Belgownie and Christon Bank health facilities are surrounded by farms which are far away from the clinics. As stated by one of the participants,

"Our roads are poor, no transporter comes here. Servicing the car is too expensive. Sometimes those with vehicles refuse to assist clients because of the state of the roads."

Riaz et al., (2015) pointed out that transportation support should be provided to the community to improve utilization of $\mathrm{MCH}$ services. Findings from the study show that transport unavailability may influence $\mathrm{MCH}$ service utilization.

\section{Long distance}

Long distance has been cited as one of the major barriers to access MCH services in Mazowe District. Clients in the catchment area of all four health facility often walk more than $15 \mathrm{~km}$ to access MCH services. Literature clearly shows that distance is a major obstacle in client's decision to seek care (Thaddeus \& Maine 1994).

\section{Consumer cost barriers}

Participants in this study mentioned that the community meets other costs on accessing MCH services. Although maternal services were offered free of charge at the health facility, mothers have to pay to go to a referral centre. According to participants: 
"All first pregnancies are supposed to be delivered at the hospital. That is what we heard. Some people prefer to deliver at home because paying a traditional birth attendant is cheaper. You only pay $\$ 5$ to the traditional birth attendant compared to $\$ 50$ needed to hire a car to go the hospital."

Clients attach a cost in comparing delivering at an institution and delivering at home. Participants viewed that there are other costs attached to delivering at an institution compared to delivering at home, this may influence uptake of $\mathrm{MCH}$ services. These costs include buying food if a client decides to go and wait at the mothers waiting home. Cost has been a major barrier in seeking health services in Pakistan (Stephenson \& Hennink, 2004). This cost includes payment for medicines and fares spent to reach the health facility (World Bank, 2002).

\section{Unavailability of outreach services}

Unavailability of outreach services may cause in low utilization of $\mathrm{MCH}$ services. Participants reiterated that outreach services in some areas have been stopped e.g. Komani at Christon Bank health facility. The community leaders felt that there was need to resuscitate these outreach points. In some instances, outreach activities were cancelled without notice. Outreach services are important in addressing health needs of clients that are in hard to reach areas.

Participants mentioned that they were disadvantaged because they did not have VHWs. As the community dialogue progressed, participants had questions on who selects the village health worker, the qualities and qualifications of a VHW. These findings show that the community realised the need of having a VHW in their respective farms and villages.

According to Archya \& Clelane (2000), access to health services is defined as travel time to the nearest health facility and coverage by outreach workers. Therefore, coverage by VHWs and health facility staff at outreach points might improve accessibility issues.

\section{Socio-cultural barriers}

\section{Religious belief}

It was pointed out that there were some religions in the community which did not permit congregants to seek treatment from the health facility. Participants stated that other religions detain the pregnant mother at their shrine until such a time the prophet at the shrine deems fit. This practice was referred to as "Chitsidzo" in vernacular, meaning promise in English.

"Pregnant women start by going to the prophets first before coming to the health facility. The prophets might detain them for more than seven days. By the time they are released from the shrine, it's too late to go to the health facility. They deliver at home with the help of traditional birth attendance."

In a Zimbabwean study, women belonging to John Marange Apostolic church were more likely to refrain from utilizing MCH services (Van Den Huevel et al., 1999). This concurs with findings from the study. Other studies have also shown that religion is a major determinant in $\mathrm{MCH}$ service utilization (Addai, 2000). Religion may work through what Andersen and Newman (1973) describes as perception of need.

\section{Cultural beliefs}

Participants in the study pointed out that women in the community believe that they must report for ANC when the pregnancy is at an advanced stage. Reporting early to the health facility might result in abortions from bewitchment. It was stated that some traditional healers claimed to heal ailments which the health facility staff can't. The healing of cultural ailments in pregnancy was termed as "kubvisa chiga" in vernacular, translated to removing all bad fortunes that might hinder safe maternity delivery. These aliments were both described as cultural and spiritual.

Findings from the study concur with Nyamongo (2002) who views that cultural beliefs and practice often lead to self-care and often consultation with traditional healers. These factors result in treatment seeking delays not only for the mother but for the child as well (Nakagawa et al., 2001). 
DOI: $10.21522 / \mathrm{TIJPH} .2013 .05 .04 . A r t 034$

ISSN: $2520-3134$

\section{Attitude of health care provider}

Findings from the study show that previous experience of services rendered may influence the utilization of $\mathrm{MCH}$ services at health facilities. Participants mentioned that there were rude nurses at their health facilities who were transferred. However, the community was not aware that these nurses were transferred. According to one participant:

"If you use a certain road in the community to go the shops. And you meet a lion along the way. You will never use that same road again because you will be afraid of meeting the lion again. The community does not know that the lions are away."

This shows that bad previous experiences are a barrier to utilization of $\mathrm{MCH}$ services. Therefore it is crucial to reengage the community on staff changes at the health facility. So that utilization of MCH services resume as expected.

Long waiting time was also cited as a barrier to utilization of $\mathrm{MCH}$ services. Participants mentioned that nurses go for lunch for long hours. They also pointed out that pregnant mothers easily get bored and go back home without getting treatment. On the other hand, long waiting times were also caused by few nurses at the health facility. Andersen and Newman (1973) viewed that health provider behaviour influence utilization of $\mathrm{MCH}$ services.

\section{Lack of information and education}

Lack of information and education may result in women taking long to decide when they should go to the health facility. Participants reiterated that by the time women decide to go to the health facility, it might be too late. This in their view resulted in home deliveries.

The study found out that women due for ANC bookings delay going to the health facility in order to reduce the number of visits to the health facility. In ANC, women are supposed to make initial bookings when the pregnancy is below 16 weeks. After that they are expected to complete four visits or more.

Women were also not utilizing the waiting mothers' home at Holme Eden clinic. This may be due to lack of information on the importance of utilizing waiting home. In addition, it was mentioned that they find it difficult to leave other children behind and stay at the waiting home. As a result, home deliveries are high in the community. At Makope clinic, Christon Bank and Belgownie Clinic, participants viewed that home deliveries are high because there is no waiting mothers' home.

Research found out that low uptake of vitamin A might be a result of lack of information on its importance.

"Vitamin A is just a drop that is given to healthy children. Why should we come for only one drop when the child is healthy?" said a participant.

Andersen and Newman (1973) view that the need factor is the most important cause of health service utilization. If the community does not see the need for $\mathrm{MCH}$ services, the decision to seek and utilize is influenced by their perception of the need.

\section{Micro-plans}

Community leaders developed micro-plans to address challenges identified in the community dialogue per health facility. Councillors, church leaders, village political party chairpersons, farm managers, District Health Executives (DHEs), headman and Health Centre Committees were all tasked with different responsibilities to oversee the implementation of identified solutions within a specific timeframe. Table 1 below shows a consolidated participatory micro action plan developed during community dialogues. Community leaders developed participatory micro action plans which identified challenges on accessing $\mathrm{MCH}$ services, action points to address challenges, responsible person and timeline in addressing challenges. 
Table 1. Micro action plan developed to address challenges in $\mathrm{MCH}$ service utilization

\begin{tabular}{|c|c|c|c|}
\hline Challenge & Action & $\begin{array}{l}\text { Responsible } \\
\text { Person }\end{array}$ & Timeline \\
\hline $\begin{array}{l}\text { Unavailability of } \\
\text { transport- there is } \\
\text { shortage of transport } \\
\text { due to poor road } \\
\text { network, mothers } \\
\text { from far away areas } \\
\text { cannot easily access } \\
\text { health facility }\end{array}$ & $\begin{array}{l}\text { - Councillors to engage responsible } \\
\text { authorities on servicing of roads and } \\
\text { provide feedback to other community } \\
\text { leaders. } \\
\text { - Community leaders to mobilize } \\
\text { community members to fill gullies } \\
\text { whilst road works are engaged. } \\
\text { - Purchasing an ambulance. Communities } \\
\text { to contribute } \$ 1 \text { usd per household as } \\
\text { share for purchasing health facility } \\
\text { ambulance. Councillor to set up village } \\
\text { committee to organize fund collection. } \\
\text { - HCC to identify transport operators who } \\
\text { will ferry clients from home to referral } \\
\text { health facility at reasonable cost. Health } \\
\text { facility staff to provide health education } \\
\text { to these transport operators so that they } \\
\text { avoid smoking and other negative } \\
\text { behaviour whilst transporting clients. }\end{array}$ & Ward Councillor & $\begin{array}{l}\text { 31 July } \\
2015\end{array}$ \\
\hline $\begin{array}{l}\text { Long distance to } \\
\text { travel to referral } \\
\text { centre- } 60 \% \text { of the } \\
\text { clients come from } \\
\text { more than } 10 \mathrm{~km} \text { away } \\
\text { from the facility. } \\
\text { Distance to travel too } \\
\text { long, mothers prefer } \\
\text { delivering at home. }\end{array}$ & $\begin{array}{l}\text { - Health Facility to open outreach points } \\
\text { using RBF funds at these areas and } \\
\text { ensure that the outreach schedule is } \\
\text { reliable and liaise with farm owners to } \\
\text { facilitate the provision of outreach } \\
\text { points space/area so that Health Facility } \\
\text { staff can conduct outreaches } \\
\text { - Construction of Mothers waiting home } \\
\text { so that mothers from hard to reach areas } \\
\text { can stay at Health Facility to avoid } \\
\text { home deliveries. } \\
\text { - VHWs to have record of all pregnant } \\
\text { woman in community and provide } \\
\text { health education to women on } \\
\text { importance of utilizing waiting homes } \\
\text { and delivering at health facilities. } \\
\text { - Community Leaders to continue } \\
\text { encouraging clients to seek services at } \\
\text { Outreach points so that resources are } \\
\text { fully utilized. }\end{array}$ & Nurse In Charge & $\begin{array}{l}31 \\
\text { August } \\
2015\end{array}$ \\
\hline
\end{tabular}


DOI: $10.21522 / \mathrm{TIJPH} .2013 .05 .04 . A r t 034$

ISSN: $2520-3134$

\begin{tabular}{|c|c|c|c|}
\hline $\begin{array}{l}\text { Socio-cultural Beliefs- } \\
\text { Religious prophets } \\
\text { detaining mothers at } \\
\text { their shrines, causing } \\
\text { delay in seeking } \\
\text { health services. }\end{array}$ & $\begin{array}{l}\text { - Intensify health education to the } \\
\text { community through conducting regular } \\
\text { dialogues with both community leaders } \\
\text { and community after every } 3 \text { months to } \\
\text { provide more information on available } \\
\text { MCH services. } \\
\text { - VHW to collect information on } \\
\text { religious objectors in the community } \\
\text { and aggregate statistics according to age } \\
\text { groups. } \\
\text { - VHWs to engage community leaders } \\
\text { and local church leaders on importance } \\
\text { of utilizing available MCH services. }\end{array}$ & VHW Chairperson & $\begin{array}{l}30 \\
\text { Novembe } \\
\text { r } 2015\end{array}$ \\
\hline $\begin{array}{l}\text { Long waiting time at } \\
\text { health facility- } \\
\text { pregnant mothers } \\
\text { waiting too long in the } \\
\text { queue, this } \\
\text { discourages them } \\
\text { from seeking } \mathrm{MCH} \\
\text { services }\end{array}$ & $\begin{array}{l}\text { HCC to conduct three meetings with } \\
\text { district health executive in meetings to } \\
\text { advocate for more nurses to the Health } \\
\text { facility. }\end{array}$ & HCC chairperson & $\begin{array}{l}31 \\
\text { August } \\
2015\end{array}$ \\
\hline $\begin{array}{l}\text { Lack of Information } \\
\text { and education on } \\
\text { importance of } \\
\text { Vitamin A } \\
\text { administration to } \\
\text { children }\end{array}$ & $\begin{array}{l}\text { - Health facility staff to conduct } \\
\text { awareness campaigns in the community } \\
\text { on importance of vitamin A and child } \\
\text { health services every quarter. AREX } \\
\text { Manager confirmed among other } \\
\text { leaders to invite Health facility staff on } \\
\text { field days, ward shows so that the } \\
\text { community gets health education. }\end{array}$ & $\begin{array}{l}\text { Health Promotions } \\
\text { Officer }\end{array}$ & $\begin{array}{l}30 \\
\text { Novembe } \\
\text { r } 2015\end{array}$ \\
\hline $\begin{array}{l}\text { Poor health facility } \\
\text { attitude-nurses refuse } \\
\text { to wake up at night } \\
\text { and mothers end up } \\
\text { delivering out of the } \\
\text { health facility }\end{array}$ & $\begin{array}{l}\text { - HCC to hold meeting with health } \\
\text { facility staff to address attitude issues } \\
\text { and engage the DHE if there are no } \\
\text { changes. } \\
\text { - HCC to follow grievance procedure on } \\
\text { community concerns raised on nurses } \\
\text { attitude. }\end{array}$ & $\begin{array}{l}\text { Community } \\
\text { Health Nurse }\end{array}$ & $\begin{array}{l}30^{\text {th }} \text { July } \\
2015\end{array}$ \\
\hline
\end{tabular}

Due to diversity of communities, similar challenges identified were tasked to different leaders as shown in the tables above. The identified actions are implementable using available resources.

\section{Community dialogues}

Findings from the study show that community dialogues are informative and allow shared decision making with health facility staff. In addition, participants mentioned that community dialogues are an effective way of discussing community issues and provide information on health matters. Community dialogues draw upon a theoretical framework that identifies individuals as agents that can interpret information (Valente \& Fosados, 2006). Unlike traditional information, dialogues recognize the community agency and allows for two way communication that enables collective action. Community leaders through dialogues are given an opportunity to learn, be informed of health issues and exert influence to community members on positive health seeking behaviour. 


\section{Conclusion}

The results from the study show that accessibility issues may be the major barrier to utilization of $\mathrm{MCH}$ services in Mazowe District. Findings from the study show that efforts should be made towards addressing accessibility issues to improve uptake of $\mathrm{MCH}$ services. Issues of transport unavailability, poor road network, unavailability of outreach services, consumer costs, and distance may influence utilization of $\mathrm{MCH}$ services. Sociocultural beliefs, and lack of information and education may also influence uptake of $\mathrm{MCH}$ services.

Community dialogues with community leaders provide insight into understanding barriers to utilization of $\mathrm{MCH}$ services in Mazowe. In addition, community dialogues allow shared decision making and designing of participatory micro-action plans that are implementable using local resources.

\section{Recommendations}

- The MoHCC should consider resuscitating MCH mobile outreach teams to address accessibility issues at health facility level.

- The Government of Zimbabwe should consider initiating Community Based Health Insurance schemes in rural areas. As much as RBF provides insurance to the mother at Health facility level, clients incur costs at the community level. These consumer costs provide a barrier to utilization of MCH services. Communities can initiate loan schemes that allow borrowing for $\mathrm{MCH}$ issues only.

- There is need to scale up community dialogues to other health facilities targeting different groups in order to elicit information on barriers to utilization of $\mathrm{MCH}$ services: For sustainability purposes, there is need to train Community Based Community Dialogue facilitators that can conduct dialogues with various groups in the community. Dialogue reports should be collated at district level by the Health Promotion Office. The findings should inform policy from community level, and thus using the Bottom up Approach.

- Further research should be conducted on Determinants of utilization of MCH services in Mazowe District, so that there is more information on barriers to utilization of $\mathrm{MCH}$ services.

- Empowering Faith Based Organizations (FBOs) and religious leaders on importance of utilizing MCH services provided at health facilities will provide a window of opportunity to address social and cultural barriers. FBOs have close links in the community since they have many followers.

- To improve uptake of Vitamin A, consideration should be done at National level to involve VHWs in its administration to under-fives. VHWs are present in almost all villages.

\section{References}

[1]. Andersen, R.M. and Newman, J.F. (1973), "Social and individual determinants of medical care utilization in the United States", Milbank Memorial Quarterly, Vol. 51, pp. 95-124.

[2]. Financing in Health", Centre for Global development, accessed from http://www.researchgate.net/publication/267399930.

[3]. Loewenson, R., Kadungure, A., Shamu, S. and Laver, S. (2012), "Assessment of facilitators and barriers to maternal and child health services in four rural and urban districts of Zimbabwe", Training and Multiple Indicator Monitoring Survey, UNICEF, 2009.

[4]. Minkler, M. and Wallerstein, N. (2005), "Improving Health through Community Organization and Community Building: A Health Perspective. Community organizing and Community Building for Health", Second edition, The State University of New Jersey. pp. 26-50.

[5]. Research Support Centre (TARSC) Report with UNICEF Collaborating Centre for Operational Research and Evaluation (CCORE) Report.

[6]. Result Based Management Mazowe District Work plan. (2015), unpublished quarterly work plan report.

[7]. Save doff, W.D. (2010), "Results-Based Financing for Health Basic Economics of Results-Based United Nations Zimbabwe (2013), "Maternal Mortality in Zimbabwe: Evidence, Costs, Implications", Issue Paper Series, United Nations Zimbabwe Publication Paper 1. 
DOI: $10.21522 / \mathrm{TIJPH} .2013 .05 .04 . \mathrm{Art} 034$

ISSN: $2520-3134$

[8]. Valente, T.W., \& Fosados, R. (2006), "Diffusion of innovations and network segmentation: The part played by people in the promotion of health", Journal of Sexually Transmitted Disease, 33, S23-S31.

[9]. (The) World Bank (2013), News, Harare, Press Release. 